\title{
Consultative Authoritarianism: The Key to Good Governance in China?
}

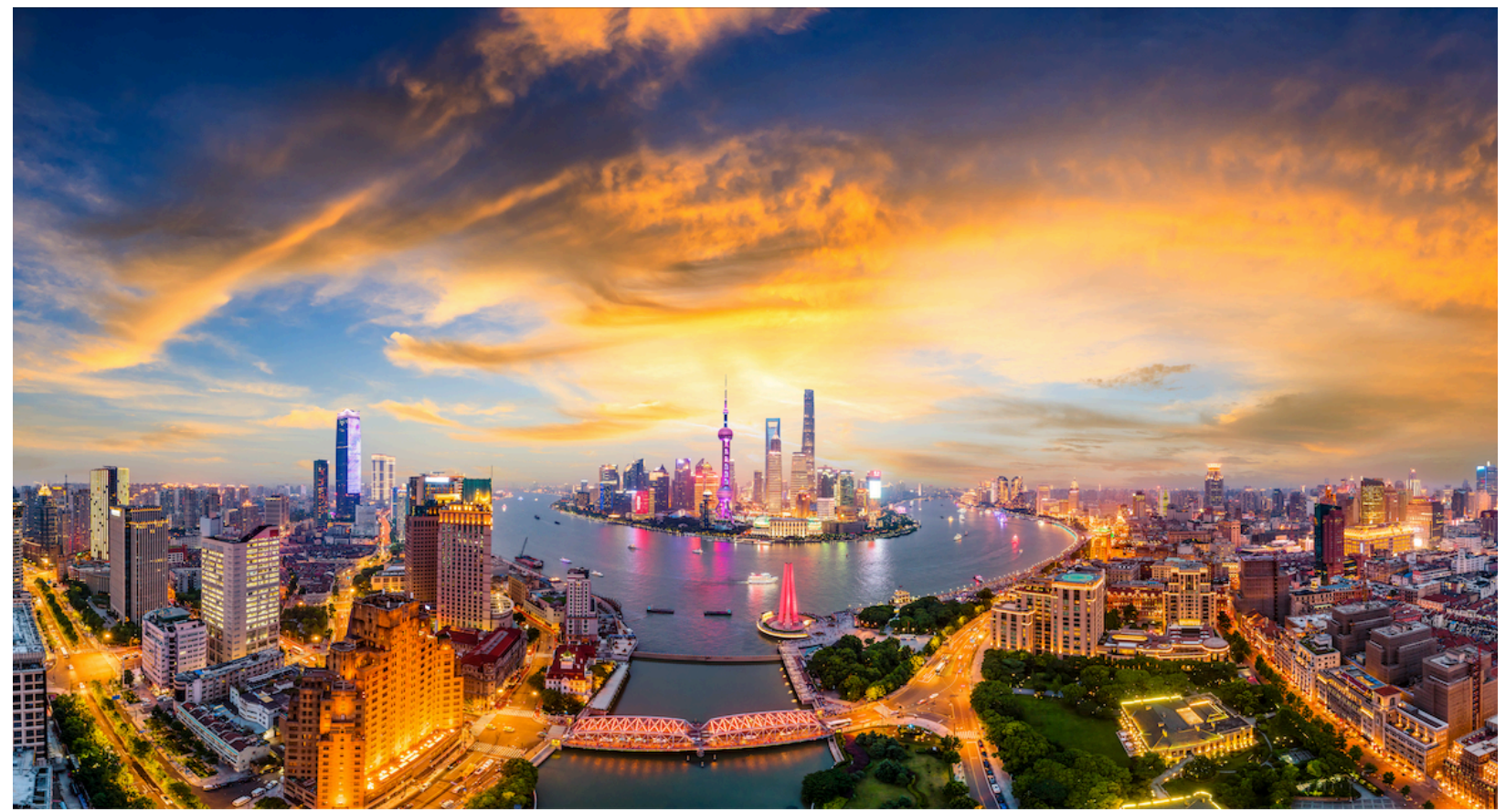

\section{Jessica C. Teets}

Associate Professor |Political Science Department | Middlebury College

Associate Editor of the Journal of Chinese Political Science

Symposium on Authoritarianism and Good Governance

Muqtedar Khan (Ed.)

International Institute of Islamic Thought | February 2021

DOI: http://doi.org/10.47816/02.001.22 
In 2014, I published a book

entitled Civil Society under

Authoritarianism, in which I addressed

the puzzle of why the strong state in

China did not repress emerging civil

society, but instead allowed these groups

to form and, in some policy areas, even

actively supported their development

and projects. I argued that over time

government officials learned that these

groups could improve local governance,

and in response, they tried to balance

between gaining these benefits while

avoiding the dangers of potential citizen

mobilization and protest. I used the

concept of "consultative

authoritarianism" to describe this

specific combination of improving

governance through consultation with

civil society while developing a

supervision structure that controlled

these organizations. I emphasized the

authoritarian nature of this system to

warn democratization scholars that this emerging civil society should not be understood as a precursor to a process of democratization. In much the same way that other scholars were demonstrating that authoritarian regimes could repurpose democratic institutions like elections and parliaments to address elite conflict (Gandhi and Lust-Okar 2009), I found that civil society could develop in a nondemocratic setting. In fact, civil society contributed to more responsive governance by ameliorating welfare and other policy problems, and helped create more durable regimes. Thus, rather than being a challenger, it could also be a partner to authoritarian governments.

The logic underlying why a strong authoritarian government would allow civil society activity is rooted in the information problems faced by such regimes. Unlike democracies, authoritarian regimes do not have good 
sources of unbiased information. These regimes usually strictly control media, and elites often do not have incentives to share information on preferences with leaders (Brownlee 2007). In democracies, elites can gain political power when they publicly defect from leaders or expose corruption unlike elites in authoritarian regimes; thus, rulers suffer from a lack of knowledge about preferences of citizens and other elites. In addition to the problems this dearth of information causes for elite cohesion (Svolik 2012), it also leads to obstacles for good governance in the form of principle-agent issues between central and local leaders. If central government leaders do not know how policies are performing in far-flung locales or whether local state agents are following regulations or engaging in corruption, this generates unsurmountable hurdles for formulating good policies and having responsive government. One way that leaders in

China responded to this paucity of knowledge was to empower civil society organizations (CSOs) to create transparency around local problems (Yang, Zhang and Wang 2020). This built low-cost flows of reliable information about policy and local agent performance that the state could use to improve governance and strengthen authoritarian resilience.

The time period encompassed by my research was from the late-1990s to 2013, spanning the administrations of both Jiang Zemin (1993-2003) and Hu Jintao (2003-2013). These two administrations supervised civil society using a 'dual registration' system, where groups needed a professional supervisory unit like a government agency and to register with the Ministry of Civil Affairs (MCA). This system prioritized control over groups by using 
risk-sharing between supervisory agencies and CSOs, and by requiring that organizations registering with MCA had a certain amount of funding. This high bar for registration resulted in a growing area of "grey civil society" where many groups operated quite openly but without formal registration (Hildebrandt 2011). In recognition of the ineffectiveness of this system, Hu Jintao allowed some local leaders to experiment with permitting CSOs to register directly with MCA and no longer required a supervisory agency. As it evolved throughout the 2000s, this supervision model resulted in the consultative authoritarianism model I described above, creating channels whereby citizens were able to improve governance even under the conditions of authoritarianism.

However, in 2013, political power shifted from $\mathrm{Hu}$ Jintao to the new
President, Xi Jinping, who began to change civil society governance. In 2016, two laws regulating CSOs were passed the Charity Law (for domestic CSOs) and FNGO law (for foreign NGOs). The FNGO law required that overseas NGOs would come under the authority of the Ministry of Public Security and be required to have a supervisory agency, similar to the former requirement for domestic CSOs. In short, moving overseas NGOs under the Public Security Bureau demonstrated that the Chinese Communist Party viewed their work as falling within the purview of law and order and social stability, rather than of civil affairs (Teets and Hsu 2016). In balance, this law increased state control over foreign NGOs in return for a more regular legal status, such as having Chinese bank accounts and a tax-deductible standing. In contradistinction, the domestic charity law codified the existing practice of 
many provinces to ease registration by

eliminating the need for a supervisory agency and only requiring direct registration with MCA; it also encouraged private donations by changing tax laws and offered more government funding through grants and contracting (Sun 2019).

Scholars reacted to these changes by trying to determine if Xi Jinping was attempting to standardize different provincial practices or simply suppress this nascent civil society. For example, Fu and Distelhorst (2018) find increasing repression under Xi Jinping. For example, Xu Zhiyong's case is illustrative of this repressive trend. When his CSO Gongmeng (New Constitution Initiative), was forced to close, he believed that space no longer existed for CSOs and decided to "organize without organization" by forming an online community called the
New Citizens Movement (NCM) (Pils 2017: 133). He is currently being held for trial again for critiquing Xi's handling of COVID-19 (South China Morning Post 2020). As Béja (2019: 223) argues, the

Party has adopted a two-pronged approach: "On one hand, it has encouraged the development of those that provide various kinds of services, and, on the other hand, it has attempted to eradicate grassroots advocacy organizations. Even the term 'civil society' (gongmin shehui) has become taboo." These changes raise the question of whether China still practices the consultative authoritarianism model, and if not, the implications of this shift.

\section{Do These Changes Challenge the Concept of Consultative} Authoritarianism?

Most of the foreign NGOs active in China have been able to register 
under the new regulations or file

documentation for "temporary

activities," which does not require a

professional supervisory agency, making

the process less onerous. The Overseas

NGO Law went into effect on January 1, 2017, and as of November 2018,

overseas NGOs had registered 427

representative offices and filed 1,179

temporary activities (Shieh and Sidel

2019). Foreign NGOs have noted

difficulties in gaining quick approval for

certain projects with local partners

along with increased inspection of

activities through project approvals and

the annual work report. This annual

report must include financial

statements, auditing reports, and

information on donations, as well as any

changes in staffing or organization.

Thus, despite these modifications that

have made operating in China more

cumbersome, foreign NGOs have mostly

continued their work.
Domestic charities have

experienced a dramatic shift in funding

sources since the law went into effect,

shifting from mostly international grant

funding to domestic fundraising and

government grants: “Ten years ago,

many rights-based CSOs I spoke with

had $80-90 \%$ of their funding coming

from international sources. Now, some

of these CSOs have 80-90\% coming

from Chinese sources. The Chinese

CSOs I interviewed had tapped into

many of these local sources-local

philanthropy, government fees-for-

service, corporate partnerships, social

enterprise, and crowdfunding” (Shieh

2020). As Dong and Lu (2020) find, many organizations now are primarily

funded by government contracts. This

shift in funding combined with

heightened political sensitivities to

result in the closure of many smaller

grassroots groups and a few high-profile

closures and arrests. The combined 
effects reinforce the centralized

leadership of the Party-what Kang

Xiaoguang calls "administrative

absorption of society” (Kang 2018).

Thus far, it appears that civil society under Xi Jinping faces more constraints than under Hu Jintao, but also has new opportunities in the realms of fundraising and still offers limited channels for policy advocacy. The codification of CSO legal status, new taxation rules on donations, and the expansion of government contracting have created more diverse funding streams. Additionally, in certain policy areas like the environment, CSOs have gained legal standing to sue local polluters. Consultative Authoritarianism still functions in China, but this model has shifted to less open consultation and the use of more authoritarian tools like repression.

\section{Implications of 'Less Consultation- More Authoritarianism' for Governance}

Xi Jinping's political logic differs from that of both Jiang Zemin and Hu Jintao in that it focuses more on the centralization of governance under the Party. Xi believes his institutional changes around promotion and anticorruption, along with support from digital governance (Gao 2020), will return enough information to the central government to develop good policies and monitor the behavior of local officials. Although the role for civil society appears much more limited under this centralized governance model, Xi does not seem to want to completely repress or ban CSOs. This new model of 'limited consultation and more authoritarianism' is best understood as a professional contracting relationship rather than one based on 
advocacy. Larger, older, and more professional CSOs, like Friends of Nature, are allowed a participatory role, such as being allowed to investigate and sue local polluters as well as the government agents that protect them; however, those working on topics deemed solidly under the domain of government or those that might challenge state authority face more repression. The tolerance for groups that are grassroots advocacy organizations, or founders who might rhetorically challenge state authority but also run beneficial projects, has disappeared. Although some of the changes under Xi Jinping were necessary to professionalize CSOs and standardize regulations, there is also a danger that they undermine the benefits of the consultative authoritarianism model.

What does this mean for the ability of the new version of the consultative authoritarianism model to improve governance under authoritarianism? Although I cannot predict the future, I would expect that CSOs will still function effectively in China, but only the bigger groups that work more closely with the state through "performance-based collaboration" (Shen and Yu 2017). Concerned citizens will continue to provide information to improve governance, but mostly in coordination with government agencies or through well-established CSOs (Anderson, Buntaine, Liu and Zhang 2019). Given the strengths of the more balanced consultative authoritarianism model, this new model will likely provide less information on unintended consequences of policies. Additionally, digital monitoring of measures like environmental targets will only deliver quantitative results, but not necessarily all information required to make good decisions. For example, to meet 
environmental targets, many officials simply shut down all factories rather than identifying the ones who are trying to improve environmental technology, often leading to unemployment and unrest (Gao and Teets 2020; Li and Shapiro 2020). This model will still outperform those types of authoritarianism with less information; however, it will not deliver the same governance benefits, resulting in a less responsive state.

Outside of China, aspects of this model of consultative authoritarianism have been adopted by over 50 countries, both democracies and autocracies (Gilbert and Mohseni 2018; Poppe and Wolff 2017). This mirrors the growing illiberal wave around the world:

"Countries that suffered setbacks in 2019 outnumbered those making gains by nearly two to one, marking the 14th consecutive year of deterioration in global freedom. During this period, 25 of the world's 41 established democracies experienced net losses" (Freedom House 2020). These trends of growing authoritarianism and less consultation with CSOs inside of China and around the world suggest troubling implications for nascent civil societies and responsive governance. Civil society offers reliable information for authoritarian regimes about policy performance, citizen satisfaction, and elite cohesion, and this knowledge then creates more durable regimes by improving performance legitimacy and establishes channels for collaborative governance with active citizens and other elites. Without this, regimes must use increased repression to ensure obedience, which is both more expensive and less successful, and frequently triggers challenges to authoritarian rule (Svolik 2012). 


\section{Author Bio}

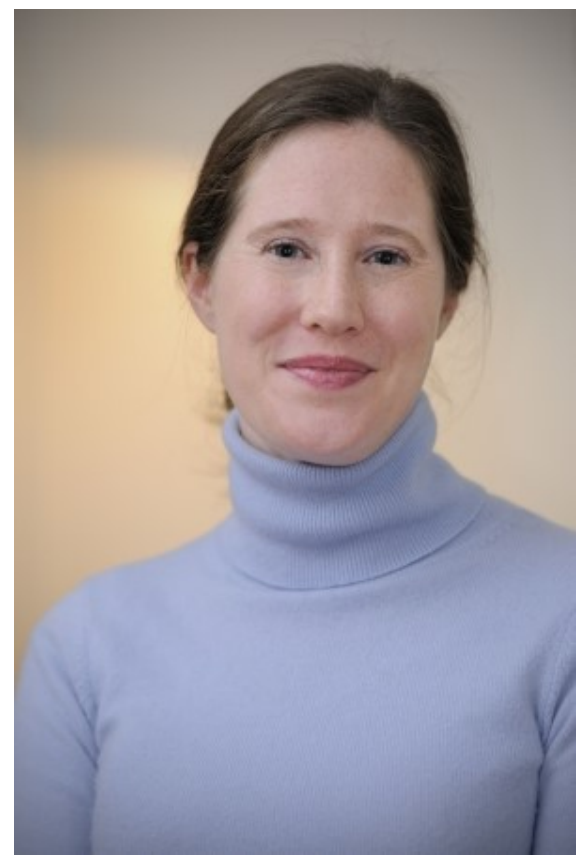

Jessica C. Teets is an Associate

Professor in the Political Science

Department at Middlebury College, and Associate Editor of the Journal of Chinese Political Science. Her research focuses on governance and policy diffusion in authoritarian regimes, specifically the role of civil society. She is the author of Civil Society Under Authoritarianism: The China Model (Cambridge University Press, 2014) and editor (with William Hurst) of Local Governance Innovation in China: Experimentation, Diffusion, and Defiance (Routledge Contemporary China Series, 2014). Dr. Teets was recently selected to participate in the Public Intellectuals Program created by the National Committee on United States-China Relations (NCUSCR), and is currently researching policy experimentation by local governments in China. 


\section{Works Cited}

Anderson, S. E., Buntaine, M. T., Liu, M., \& Zhang, B. 2019. Non-Governmental Monitoring of Local Governments Increases Compliance with Central Mandates: A National-Scale Field Experiment in China. American Journal of Political Science, 63(3), 626-643.

Béja, J. 2019. Xi Jinping's China: On the Road to Neo-totalitarianism. Social Research: An International Quarterly 86(1), 203-230.

Brownlee, J. 2007. Authoritarianism in an Age of Democratization. Cambridge and New York: Cambridge University Press.

Dong Q and Lu J. 2020. In the Shadow of the Government: The Chinese Nonprofit Sector in the COVID-19 Crisis. The American Review of Public Administration 50(67):784-789.

Fu, Diana and Distelhorst, G. 2018. Grassroots participation and repression under $\mathrm{Hu}$ Jintao and Xi Jinping. The China Journal, 79(1), 100-122.

Freedom House. 2020. Freedom in the World 2020: A Leaderless Struggle for Democracy. Accessed August 2020: https://freedomhouse.org/report/freedomworld/2020/leaderless-struggle-democracy

Gandhi, Jennifer and Ellen Lust-Okar, 2009. Elections under Authoritarianism, Annual Review of Political Science 12: 403-422.

Gao, Xiang. 2020. State-Society Relations in China's State-Led Digitalization. China Review, 2O(3), 1-12.

Gao, X., \& Teets, J. 2020. Civil society organizations in China: Navigating the local government for more inclusive environmental governance. China Information.

Gilbert, Leah, and Payam Mohseni. 2018. Disabling dissent: the colour revolutions, autocratic linkages, and civil society regulations in hybrid regimes. Contemporary Politics 24.4: 454-480.

Hildebrandt, Timothy. 2011. The political economy of social organization registration in China. The China Quarterly, 208, pp.970-989.

Kang Xiaoguang. 2018. Moving toward Neo-Totalitarianism: A Political-Sociological Analysis of the Evolution of Administrative Absorption of Society. Non-Profit Policy Forum 2018.

Li, Yifei and Judith Shapiro. 2020. China goes Green: coercive environmentalism for a troubled planet. John Wiley \& Sons.

Pils, Eva. 2017. From Independent Lawyer Groups to Civic Opposition: The Case of China's New Citizens Movement. Asian-Pacific Law \& Policy Journal 19 (1): 110-52. 
Poppe, Annika Elena, and Jonas Wolff. 2017. The contested spaces of civil society in a plural world: norm contestation in the debate about restrictions on international civil society support. Contemporary Politics 23.4: 469-488.

Shen, Yongdong and Jianxing Yu. 2017. Local government and NGOs in China: Performance-based collaboration. China: An International Journal, 15(2), pp.177-191.

Shieh, Shawn and Mark Sidel. 2019. Nonprofit Law in China. Accessed December 18, 2020: https://www.cof.org/content/nonprofit-law-china

Shieh, Shawn. 2020. Is China the future for hybrid CSO funding models? Accessed June 2020: https://www.openglobalrights.org/is-china-the-future-for-hybrid-cso-fundingmodels/

South China Morning Post. 6 February 2020. "Chinese scholar blames Xi Jinping, Communist Party for not controlling coronavirus outbreak."

Sun, T. 201). Deliberate Differentiation by the Chinese State: Outsourcing Responsibility for Governance. The China Quarterly, 240, 880-905.

Svolik, MW. 2012 The Politics of Authoritarian Rule. Cambridge and New York: Cambridge University Press.

Teets, Jessica and Hsu, C., 2016. Is China's new overseas NGO management law sounding the death knell for civil society? Maybe not. The Asia-Pacific Journal, 14(4).

Teets, Jessica. 2014. Civil society under authoritarianism: The China model. Cambridge and New York: Cambridge University Press.

Yang, Fan, Zhihan Zhang and Shizong Wang, 2020. Enlisting citizens: forging the effectiveness of policy implementation in local China, Journal of Chinese Governance. 